\title{
ELAINE SHOWALTER COLLECTION BIBLIOGRAPHY
}

Elaine Showalter's generous gift primarily of books by and about Victorian British women authors to the Rutgers University Libraries contains nearly 500 titles in 652 volumes. This bibliography was extracted from Rutgers' online public catalog, IRIS, by Robert Warwick and edited for publication here by Michael Joseph and Robert G. Sewell. Most of the books are available in the Alexander Library stacks, and a few dozen, in Special Collections and University Archives, also located in the Alexander Library. The Showalter Collection was cataloged with the aid of agrant from the New Jersey Council for the Humanities.

The Argosy. London: Bentley and Son, 1866-77.

The Model20th Century Speaker: A Book of Entertainment for Home, Schooland Church:Recitations, Readings, Plays, Drills, Tableux, Etc, Together with Rules for Physical Culture and for the Training of the Voice and the Use of Gesture, According to the Delsarte System by Frances Putnam Pogle. Numerous new and original Musical Compositions for Special Entertainments, etc:: with Many Old Favorites. Compiled and written by George M. Vickers. 1902.

OurFamous Women:AnAuthorizedRecord of the Lives andDeeds of Distinguished American Women of Our Times, by Elizabeth Stuart Phelps. Freeport, N.Y.: Books for Libraries Press, [1975].

Queens of the Circulating Library: Selections from Victorian Lady Novelists, I850-1900. Walbank, F. Alan, ed. London: Evans, I950.

Stories by English Authors. New York: Scribner, 1896.

A Treasury of Plays for Women. Edited by Frank Shay. Boston: Little, Brown, 1923.

Women as Letter-Writers: A Collection of Letters. Selected and edited by Ada M. [Ada De la Mare] Ingpen. New York: Baker and Taylor, [I909?].

Women Novelists of Queen Victorias Reign: A Book of Appreciations. London: Hurst \& Blackett, 1897.

Women's Franchise. [London:Women Citizen Pub. Society], 1907-09. 
Addams, Jane. The Long Road of Woman's Memory. New York: Macmillan, [1916].

A New Conscience and an Ancient. New York: Macmillan, I9I2.

Aguilar, Grace. The Days of Bruce: A Story from Scottish History. New York: Appleton, 1907.

Home Influence: A Tale for Mothers and Daughters. New ed. New York: Appleton, I888.

. The Mother's Recompense: A Sequel to Home Influence. New ed. New York: Appleton, 1904.

Alcott, Louisa May. Aunt Jo’s Scrap-Bag. Boston: Roberts, I889. I886.

Jack and Jill: A Village Story with illustrations. Boston: Roberts,

Alcott, William A. The Young Husband; or Duties of Man in the Marriage Relation. Fifth stereotype ed. Boston: Light, I840 [c. I838].

Amiel, Henri Frédéric. [Journal intime. English. I885.] Amiel's Journal: The Journal in Time of Henri-Frédéric Amiel. Translated with an introduction and notes by Mrs. Humphry Ward. London: Macmillan, I9I5.

Armstrong, Margaret. Fanny Kemble: A Passionate Victorian. New York: Macmillan, 1938.

Atherton, Gertrude Franklin Horn. The Conqueror: A Dramatized Biography of Alexander Hamilton. New York: Stokes, [1928].

Barber, MargaretFairless. The Complete Works of Michael Fairless. Biographical note by M.E. Dowson. [London]: Duckworth, [I93I].

Battiscombe, Georgina. Charlotte Mary Yonge: The Story of an Uneventful Life. Introduction by E.M. Delafield; with illustrations and genealogies. London: Constable, [1943].

Beecher, Mrs. Henry Ward. All Around the House, or, How to Make Homes Happy. New York: Appleton, I879.

Benson, Stella. The Little World. London: Macmillan, I925. 
Betham-Edwards, Matilda. Holidays Among the Mountains, or, Scenes and Stories of Wales; with illustrations by F.J. Skill. London: Griffith and Farran; New York: Dutton, [18-?].

Mid-Victorian Memories. With a personal sketch by Mrs. Sarah Grand. London: J. Murray, I9I9.

Black, Helen C. Notable Women Authors of the Day. London: Maclaren, I906.

Booth-Tucker, Frederick St. George De Lautour. The Short Life of Catherine Booth:The Mother of the Salvation Army. Abridged from the original ed. London: Salvation Army, [I893].

Braddon, M.E. (Mary Elizabeth). Gerard, or, the World, the Flesh, and the Devil. Stereotyped ed. London: Simpkin, Marshall, Hamilton, Kent, I892.

—. Hostages to Fortune. Stereotype ed. London: Maxwell, I878.

_. Ishmael. London: Maxwell, [I885].

- Like and Unlike. Stereotyped ed. London: Simpkin, Marshall, [ca. I880?].

- London Pride, or, When the World. New ed. Simpkin, Marshall, Hamilton, Kent, [18-?].

—. The Octoroon. Chicago: Conkey, [between I900 and I9I0?]. Tyler, [18-?].

. Taken at the Flood. Stereotype ed. London: Ward, Lock, and . The Venetians. Stereotype ed. London: Simkin, Marshall, Hamilton, Kent, 1893.

—. Vixen. Stereotype ed. London: Maxwell, [18-?].

Brame, Charlotte M. Dora Thorne. New York: Lupton, [I8-?].

—. Dora Thorne. New York: Mershon, [18-?].

—. The Duke’s Secret. New York: Lupton, [18-?].

—. A Woman's Temptation. [n.p.]: Butler Brothers, [18-?]. (Published under the pseudonym by Bertha M. Clay.) 
Brittain, Vera. Testament of Friendship: the Story of Winifred. New York: Macmillan, I940.

Bronte, Anne. The Tenant of Wildfell Hall. London: Smith, Elder, 1884.

Bronte, Charlotte. The Professor. New York: Hurst, [18-?].

Broughton, Rhoda. The Beginner. London: R. Bentley and Son, I894.

. Cometh Up as a Flower. New York: Munro, [I8-?].

- Cometh Up as a Flower: An Autobiography. London: Macmillan, I899.

- The Game and the Candle. [London]: Macmillan, [I8-?]

_. Good-bye, Sweetheart. New York: Munro, [18-?].

- Nancy. New York: Syndicate Trading Company, [18-?].

—. Not Wisely but Too Well. 8th ed. London: Bentley and Son, I893.

—. Second Thoughts. New York: Appleton, I880.

Browning, Elizabeth Barrett. Aurora Leigh: a Poem. New York: Worthington, I890.

Browning, Oscar. Life of George Eliot. London: Scott, 1892.

Burnett, Frances Hodgson. A Lady of Quality; Being a Most Curious, Hitherto Unknown History, as Related by Mr. Isaac Bickerstaff, but Not Presented to the World of Fashion Through the Pages of the Tatler, and Now for the First Time Down. London: Warne, 1896.

. Little Lord Fauntleroy. Newly illustrated by Reginald Birch. New York: C. Scribner's Sons, I9I5.

—. T. Tembarom. London: Hodder and Stoughton, [19-?].

Burney, Fanny. Evelina; or, The History of a Young Lady's Entrance into the World. Edited by R. Brimley Johnson; illustrated by W. Cubitt Cooke. London: Dent, 1893.

- Fanny Burney and Her Friends: Select Passages from Her Diary and Other Writings. Edited by L.B. Seeley; with nine illustrations after Reynolds, Gainsborough, Copley, andWest. London: Seeley, [I87I]. Large paper ed. limited to I50 copies. 
Carey, Rosa Nouchette. The Angel of Forgiveness. London: Macmillan, 1909.

—. Aunt Diana. London: The offices of "The Girl's Own Paper", [19-?].

_. Barbara Heathcote’s Trial. London: Macmillan, 1904.

—. Basil Lyndhurst. New ed. London: R. Bentley \& Son, I894.

—. Doctor Luttrell's First Patient.2nd ed. London: Hutchinson, [19-?].

—. Little Miss Muffet. London: Religious Tract Society, [19-?].

—. Mary St. John. London; New York: Macmillan, I903.

-The Mistress of Brae Farm. London: R. Bentley \& Son, I897.

—. The Mistress of Brae Farm. London: Macmillan, 1906.

- Mrs. Romney; and, 'But Men MustWork'. New ed. London; New York: Macmillan, I90I.

. My Lady Frivol. With sixteen full-page illustrations by Bertha Newcombe. London: Hutchinson, [I8-?].

Nellie's Memories: A Domestic Story. New ed. London: R. Bentley and Son, I898.

- Not Like Other Girls. New and cheaper ed. London: Macmillan, I898.

—. Not Like Other Girls. New York: Allison, [I8-?].

—. Rue with a Difference. London: Macmillan, I9I4.

- The Sunny Side of the Hill. London: Macmillan, 1920.

Carlyle, Jane Welsh. Letters and Memorials of Jane Welsh Carlyle. Prepared for publication by Thomas Carlyle; edited by James Anthony Froude. London: Longmans, Green, I883.

Carroll, Lewis. [Alice's Adventures in Wonderland. French] Aventures D'Alice au Pays des Merveilles. Illustrées par Arthur Rackham. Paris: Hachette, I9I0.

Cather, Willa. The Professor's House. New York: Grosset \& Dunlap, c. 1925. 
Cecil, David, Lord. The Young Melbourne and the Story of His Marriage with Caroline Lamb. Foreword by Carl Van Doren. New York: The Press of the Readers Club, [1943].

Charlesworth, Maria Louisa. Ministering Children. London: Pickering \& Inglis, [I8-?].

- The Ministry of Life. New York: Appleton, 1864.

Cholmondeley, Mary. The Danvers Jewels; and, Sir Charles Danvers. New York; London: Harper \& Brothers, I90I.

—. Red Pottage. New York: Harper \& Brothers, 1900.

Clarke, Mary Cowden. The Girlhood of Shakespeare's Heroines: In a Series of Tales. First Series. New York: G.P. Putnam’s Sons, I878.

Clarke, Rebecca Sophia. Quinnebasset Girls. Boston: Lee and Shepard, I877.

Cleghorn, Sarah Nordiffe. The Spinster: a NovelWherein: A Nineteenth Century Girl Finds Her Place in the Twentieth. New York: Holt, I9I6.

Clement, J. [Jesse]. Noble Deeds of American Women: with Biographical Sketches of Some of the More Prominent. With an introduction by Mrs. L. H. Sigourney. Buffalo: Geo. H. Derby, I85I.

Clifford, Mrs.W.K., Love Letters of a Worldly Woman. New York: Caldwell, [19-?].

Margaret Vincent. New York: Harper \& Brothers, 1902.

Coleridge, Mary E. Collected Poems. Edited with an introduction by Theresa Whistler. London: Hart-Davis, 1954.

Collins, Wilkie. The Black Robe. Copyright ed. Leipzig: Tauchnitz, I88I.

Coolidge, Susan. What Katy Did; and, What Katy Did at School. Edited by Robert Harding. London: Gawthorn, [19-?].

Corelli, Marie. Free Opinions Freely Expressed on Certain Phases of Modern Social Life and Conduct. London: Constable, 1905.

Innocent, Her Fancy and His Fact. New York: Hodder \& Stoughton, George H. Doran Co., [I9I4]. 
—. The Mighty Atom. Philadelphia: Lippincott, 1896.

- The Murder of Delicia. London: Skeffington \& Son, 1896.

- The Secret Power. New York: Burt, I92I.

. Temporal Power. A Study in Supremacy. 8th and populared. London: Methuen, [1954].

- Thelma: A Norwegian Princess. London: Methuen, [19-?].

Co., $[1886]$.

. Vendetta, or, The Story of One Forgotten. New York: Federal Book

Wormwood: A Drama of Paris. Authorized American ed. New York: Allison, [1890].

. Wormwood: a Drama of Paris. Authorized American ed. New York: Federal Book Co., [I890].

Craik, Dinah Maria Mulock. About Money and Other Things: A Gift Book. London: Macmillan, I886.

Ward, Lock, 1903.

. Agatha's Husband. Ilustrations by Florence Reason. New York: Brothers, [18-?].

Agatha's Husband. With illustrations. New York: Harper \&

_. Christian's Mistake. London: Hurst and Blackett, [I8-?].

-The Head of the Family. London: Scott, [18-?].

—. John Halifax, Gentleman. London: Dent, New York: Dutton, I9I6.

—. John Halifax, Gentleman. New York: Crowell, [I8-?].

—. A Life for a Life. London: Scott, [19-?].

. The Little Lame Prince and the Adventures of a Brownie. With an introduction by B. Ethel Webb; illustrated by Edwin J. Prittie and John Fitz, Jr. Chicago: Winston, 1928.

Miss Moore: a Tale for Girls; illustrated. New York: Harper, 1904.

—. A Noble Life. London: Hurst and Blackett, [18-?].

- The Ogilvies. London: Scott, [19-?]. 
- Olive. London: King, [18-?].

—. Poems. Author's ed. Boston: Ticknor and Fields, I866.

—. Studies from Life. London: Hurst and Blackett, I86I.

—. Studies from Life. New ed. London: Hurst and Blackett, [I8-?].

_. A Woman's Thoughts about Women. New York: Lupton, [I8-?].

Young Mrs. Jardine. Driven to Bay, by Florence Marryat. Boston:

Estes and Lauriat, [I8-?].

—. Young Mrs. Jardine. London: Hurst and Blackett, [I8-?].

(For other works by Craik see under Marryat, Florence)

Dane, Clemence. Broome Stages. Garden City, N. Y.: Doubleday, Doran, 1936

Davidson, Lucretia Maria. Poetical Remains of the Late Lucretia Maria Davidson. Collected and arranged by her mother; with a biography by Miss Sedgwick. Philadelphia: Lea and Blanchard, I84I.

Dickens, Charles. Christmas Stories. [Oxford ed.] New York: Lovell, [19-?]. Dombey and Son. With illustrations by F. Barnard. Chicago: Belford, Clarke, [18-?].

- Sketches by Boz: Illustrative of Every-day Life and Every-day People; with thirty-four illustrations by F. Barnard. London: Chapman and Hall, [I8-?]. (On cover: The Works of Charles Dickens: household edition. New York: D. Appleton \& Co.)

Dixie, Florence, Lady. Isola, or, the Disinherited: a Revolt for Woman and All the Disinherited; with remarks thereon by George Jacob Holyoake. London: Leadenhall Press; New York: Scribner, [1877].

Dowie, Ménie Muriel. Things about Our Neighbourhood. London: Grant Richards, I903. ("This ed. is issued for circulation in India and the Colonies only.")

Du Maurier, George. Trilby. With I2I illustrations by the author. London: Osgood, McIlvaine, I895. 
“The Duchess.” Dick's Sweetheart. New York: Lovell, [I8-?].

-. Hon. Mrs. Vereker. New York: Lupton, [I8-?].

—. A Life’s Remorse. New York: Lupton, [18-?].

- Marvel. New York: Lupton, [18-?].

—. A Modern Circe. [s.l.: s.n., I8-?].

Dumas, Alexandre. [Comte de Monte-Cristo. English] The Count of Monte Cristo. New York: Nelson and Sons, [19-?].

[Vicomte de Bragelonne. English]The Vicomte De Bragelonne, or, Ten Years Later. New York: Nelson, [19-?].

Eden, Emily. The Semi-attached Couple. Introduction by Anthony Eden; illustrated by Susanne Suba. Boston: Houghton Mifflin; Cambridge: Riverside Press, 1947.

Edgeworth, Maria. Belinda. Illustrated by Chris Hammond; with an introduction by Anne Thackeray Ritchie. London, New York: Macmillan, I896.

- Castle Rackrent; and, The Absentee; illustrated by Chris Hammond; with an introduction by Anne Thackeray Ritchie. London: Macmillan, I9I0.

- Castle Rackrent; the Absentee. Introduction by Brander Matthews. London: Dent, New York: Dutton, 1952.

Ormond: A Tale Illustrated by Carl Schloesser; with an introduction by Anne Thackeray Ritchie. London; New York: Macmillan, I895.

—. Tales and Novels: in Eighteen Volumes. London: Baldwin \& Cradock, I832.

Egerton, George. Fantasias. London: Lane, 1898.

Keynotes. 6th ed. London: Lane; Boston: Roberts, 1894.

Eliot, George. Felix Holt: the Radical. New York: Lovell, [I8-?].

—. A Moment Each Day with George Eliot. Chicago: Seymour, 1902.

Romola. Chicago, New York: Rand, McNally, [c. I898]. 
- Scenes of Clerical Life; And, Silas Marner. New York: Harper \& Brothers, [18-?].

Elizabeth. Christine. London: Macmillan, 19I7. (Published under name Alice Cholmondeley.)

—. Elizabeth and Her German Garden. London; New York: Macmillan, 1899.

Elliott, Ruth. Undeceived:Roman or Anglican: A Story of English Ritualism. London: Allingham, I877.

Ellis, Sarah Stickney. The Prose Works of Mrs. Ellis. New York: Langley, I844.

Evans, Augusta J. [Augusta Jane]. Beulah. New York: Grosset \& Dunlap, [19-?].

-. Infelice. London: Ward, Lock, [19-?].

—. St. Elmo. New York: Grosset \& Dunlap, 1896.

Ewing, Juliana Horatia Gatty. The Brownies, and Other Stories. Illustrated with 4 color plates and line drawings by E.H. Shepard. London, Dent; New York: Dutton, [1968].

- Jackanapes; Daddy Darwin's Dovecot; The Story of a Short Life. With a sketch of her life by her sister, Horatia K.F. Gatty; with illustrations by Gordon Browne and Randolph Caldecott. New York: International Book Company, [18-?].

- Six to Sixteen: A Story for Girls. Boston: Little, Brown, [19-?].

- The Story of a Short Life. llustrated by Gordon Browne. Boston: Little, Brown, [19-?].

Falconer, Lanoe. Cecilia de Noél. London; New York: Macmillan, I892.

Fawcett, Dame Millicent Garrett. The Women's Victory — and After: Personal Reminiscences, I9I I-I9I8. London: Sidgwick \& Jackson, [1920].

Fern, Fanny. Fern Leaves from Fanny's Portfolio. London:Ward, Lock, [18-?].

- Ginger-Snaps. New York: Carleton; London: Low, I870. 
- Ruth Hall: a Domestic Tale of the Present Time. New York: Mason Brothers, I855.

Ferrier, Susan. The Inheritance. Edinburgh: Blackwood, I824.

Finley, Martha. Elsie and Her Loved Ones. New York: Dodd, Mead, 1903.

_. Elsie’s Girlhood. New York: Dodd, Mead, 1872.

_. Elsie’s Motherhood. New York: Dodd, Mead, 1904.

_. Elsie's Womanhood. New York: Dodd, Mead, 1903.

—. Holidays at Roselands. New York: Dodd, Mead, [I898].

Fothergill, Jessie. The First Violin. London: Macmillian, 1903.

—. Kith and Kin. Popular ed. London: Bentley, I896.

Fowler, Ellen Thorneycroft. Concerning Isabel Carnaby. I3th. ed. London: Hodder and Stoughton, I899.

- A Double Thread. New York: Appleton, I899.

—. The Farringdons. London: Hutchinson, 1900.

Freeman, Mary Eleanor Wilkins. The Debtor Illustrations by W. D. Stevens. New York; London: Harper \& Brothers, cI905.

Brothers, I887.

A Humble Romance: and Other Stories. New York: Harper \& A New England Nun and Other Stories. New York: Harper \& Brothers, I89I.

—. Pembroke. New York: Harper and Brothers, I894.

- The Portion of Labor. New York, London: Harper \& Brothers, I90I.

Froude, James Anthony. Essays in Literature and History. Introduction by Hilaire Belloc. New York: Dutton, [I9II].

Gale, Zona. Miss Lulu Bett. New York; London: Appleton, I92I.

Gaskell, Elizabeth Cleghorn. Cranford. London: Harrap, 1948. 


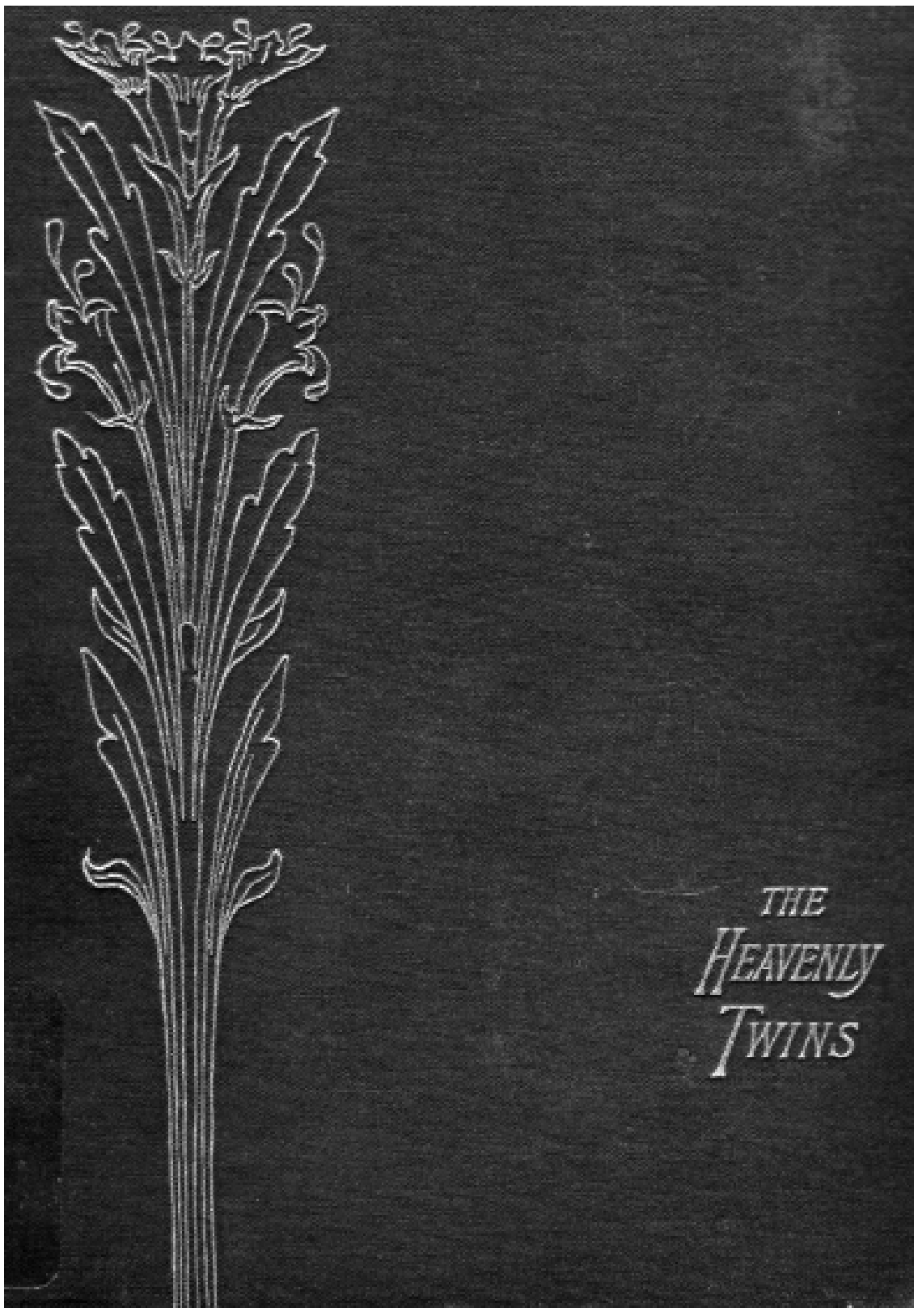

Figure 3.I Cover of Sarah Grand's Heavenly Twins (I894) from the Elaine Showalter Collection at Rutgers 
- Letters of Mrs. Gaskell and Charles Eliot Norton, I855-I865.London: Oxford University Press, H. Milford, I932.

- Ruth. New York: Garland, 1975. (Reprint of the 1853 ed. published by Chapman and Hall, London.)

Wives and Daughters: an Every-day Story. New ed., with four illustrations. London: Smith, Elder, I894.

Gatty, Mrs.Alfred. Mrs. Parables from Nature. New York: Dutton, [19-?].

Gerard, E.D. Beggar My Neighbour. New ed. Edinburgh: Blackwood and Sons, I882. Sons, I88I.

Reata: What's in a Name. New ed. Edinburgh: Blackwood and The Waters of Hercules. New ed. Edinburgh: Blackwood, I886.

Gibbons, Stella. Cold Comfort Farm. London, New York: Longmans, Green, 1957.

Gissing, George. The Private Papers of Henry Ryecroft. New York: Dutton, [1927].

Glasgow, Ellen Anderson Gholson. One Man in His Time. Garden City, N. Y.: Doubleday, Page, [I922].

- The Romantic Comedians. Garden City, N.Y.: Doubleday, Page, 1926.

Guild, I929.

They Stooped to Folly: A Comedy of Morals. Isted. New York: Literary

Glyn, Anthony. Elinor Glyn: A Biography. London: Hutchinson, [1955].

- Halcyone. New York: Burt, I9I2.

—. Three Weeks. New York: Duffield, 1907.

-The Visits of Elizabeth. 29th ed.: London; New York: Lane, I90I.

Grand, Sarah. The Beth Book: Being a Study from the Life of Elizabeth Caldwell Maclure a Woman of Genius. London: Heinemann, I898.

. The Heavenly Twins. London: Heinemann, I894. 
Gray, Maxwell. The House of Hidden Treasure. London: Heinemann, I898.

Hale, Nancy. The Prodigal Women. New York: C. Scribner's Sons, I942.

Hall, Radclyffe. Adam’s Breed. London: Cassell, [1928].

- The Master of the House. New York: Cape and Ballou, [1932].

- The Unlit Lamp. New York: Jonathan Cape and Harrison Smith, 1929.

. The Well of Loneliness. With a commentary by Havelock Ellis. Garden City, N.Y.: Sun Dial Press, cI928.

Hall, S. C. (Samuel Carter). A Book of Memories of Great Men and Women of the Age: from Personal Acquaintance. $2 \mathrm{~d}$ ed. London:Virtue, I877.

Hamilton, Gail. Katharine Frensham. Edinburgh: Blackwood and Sons, 1903.

. Woman's Wrongs: A Counter-Irritant. Boston:Ticknor and Fields, I868.

Harraden, Beatrice. Ships That Pass in the Night. New York: Lupton, [I893?].

Havergal, Maria V.G. [Maria Vernon Graham]. Memorials of Frances Ridley Havergal. By her sister, M.V.G.H. New York: Randolph, [I880].

Haweis, Mary Eliza Joy. The Art of Decoration. London: Chatto \&Windus, I889.

- The Art of Housekeeping: A Bridal Garland. London: Sampson Low, Marston, Searle, \& Rivington, I889.

Hemans, Felicia Dorothea Browne. The Poetical Works of Mrs. Hemans. With prefatory memoir, notes, etc. Albion ed. London, New York: Warne, I897.

Hicks, Mrs.Beach,William, Amabel and Mary Verena: An Epilogue. London: Faber and Faber, [1946].

Hobbes, John Oliver. The Ambassador: A Comedy in Four Acts. New York: Stokes, [1898].

The Flute of Pan. New York: Appleton, 1905. 
—. The Gods, Some Mortals and LordWickenham. London:Henry, I895. - The Lifeof John Oliver Hobbes. Told in hercorrespondence withnumerous friends with a biographical sketch by her father John Morgan Richards, and an introduction by the Right Rev. Bishop Welldon, Dean of Manchester. London: J. Murray, I9I I.

—. The Serious Wooing: a Heart's History. 2nd ed. New York: Stokes, [c. I90I].

A Study in Temptations; and, A Bundle of Life. London: Unwin, 1905.

—. The Tales of John Oliver Hobbes. New York: Stokes, c. I897.

- The Vineyard. London: Unwin, 1904.

Holley, Marietta. Miss Jones' Quilting. New York: Ogilvie, cI887. Published under pseudonym "Josiah Allen's Wife".

- [Samantha on the Race Problem] Samantha Among the Colored Folks: "My Ideas on the Race Problem." Illustrated by E.W. Kemble. New York: Dodd, Mead, I898. Published under pseudonym "Josiah Allen's Wife".

Holtby, Winifred. South Riding. New York: Macmillan, 1936.

Howe, Bea. Arbiter of Elegance. London: Harvill P., [c. I967].

Howe, Susanne. Geraldine Jewsbury: Her Life and Errors. London: Allen \& Unwin, [1935].

Hubbard, Elbert. Little Journeys to the Homes of American Authors. New York; London: G.P. Putnam's Sons, [I896]. [1907].

Little Journeys to the Homes of Famous Women. New York: Putnam, Little Journeys to the Homes of Famous Women. Memorial ed. New York, Chicago: Wise, c. I9I6.

Ibsen, Henrik. Ibsen's Prose Dramas. Edited by William Archer. Authorized English ed. London: Scott, I890-9I.

Ingelow, Jean. Fated to Be Free. Copyright ed. Leipzig:Tauchnitz, I875. . Fated to Be Free: A Story. New illustrated ed. London: Tinsley Brothers, 1876. 
—. Poems. Author's ed. Boston: Roberts, I864.

- The PoeticalWorks of Jean Ingelow: Including the Shepherd Lady and Other Poems. New York: Lovell, [1863?].

Ireland, Annie Elizabeth Nicholson. Life of Jane Welsh Carlyle. London: Chatto \& Windus, I89I.

James, Henry. Theatre and Friendship. Edited by Elizabeth Robins. London: Cape, 1934.

James, W. M. [William Milbourne]. John Ruskin and Effie Gray: The Story of John Ruskin, Effie Gray and John Everett Millais, Told for the First Time in Their Unpublished Letters. New York: C. Scribner's Sons, 1947.

Jameson, Mrs. [Anna]. Characteristics of Women, Moral, Poetical, and Historical. From the last London ed. Boston: Ticknor and Fields, I866.

Jameson, Storm. Women against Men. Ist American ed. New York: Knopf, 1933.

Jeaffreson, John Cordy. A Book of Recollections. London: Hurst \& Blackett, I894.

Jenkins, Roy. [Sir Charles Dilke] Victorian Scandal: A Biography of the Right Honorable Gentleman Sir Charles Dilke. Rev. ed. New York: Chilmark, [I965]. First ed. published under title Sir Charles Dilke: A Victorian Tragedy.

Johnston, Harry Hamilton. The Gay-Dombeys. With a preface by H.G. Wells. New York: Macmillan, I9I9.

- Mrs. Warren's Daughter: A Story of the Woman's Movement. New York: Macmillan, 1920.

Johnston, Mary. By Order of the Company. London: Constable, I908.

—. Hagar. New York: Houghton Mifflin, I9I3.

- Lewis Rand. With illustrations by F.C. Yohn. Boston, New York: Houghton Mifflin, 1908.

- The Long Roll. London: Constable, I9I I.

—. The Old Dominion. London: Constable, 1906. 
\& Dunlap, c. 1898.

Prisoners of Hope: A Tale of Colonial Virginia. New York: Grosset

- Prisoners of Hope: a Tale of Colonial Virginia. Boston: Houghton, Mifflin, [c. I898].

To Have and to Hold. With illustrations by Howard Pyle [and others]. Boston: Houghton Mifflin, I900.

Keary, Annie. The Rival Kings. Introduction by Gillian Avery. London: Gollancz, I970.

Kingsley, Charles. The Water-Babies: a Fairy Tale for a Land-Baby. With one hundred illustrations by Linley Sambourne. New York: Burt, [I8-?]. I899.

Kipling, Rudyard. The Works of Rudyard Kipling. New York: Century Co.,

Latour,Th.-Louis [Thérèse-Louis]. Princesses, Ladies \& Salonnières of the Reign of Louis XV. London: K. Paul, Trench, Trubner, 1927. [Translated from French by Ivy E. Clegg.]

Lawless, Emily. Maria Edgeworth. New York: Macmillan, 1904.

Le Feuvre, Amy. A Bit of Rough Road. Illustrated by Percy Tarrant. London: Religious Tract Society, 1908.

Lee, Vernon. Laurus Nobilis: Chapters on Art and Life. London; New York: Lane, 1909.

—. Limbo, and Other Essays. London: Richards, 1897.

- Renaissance Fancies and Studies; Being a Sequel to Euphorion. New York: G. P. Putnam’s Sons, London: Smith, Elder, 1896.

Lehmann, Rosamond. Dusty Answer. New York: Holt, 1927.

—. Invitation to the Waltz. New York: H. Holt, [c. I932].

Lyall, Edna. A Hardy Norseman. New ed. London: Hurst and Blackett, [I8-?].

- Hope, the Hermit. London; New York: Longmans, Green, I898, c. 1897. 
- In the Golden Days. New ed. London: Hurst and Blackett, I900.

-. In the Golden Days. New York: Crowell, [I8-?].

—. Knight-Errant. New York: Hurst, 1899.

—. We Two. New ed. London: Hurst and Blackett, [I89?].

—. Won by Waiting. New ed. London: Hurst and Blackett, [1900?].

Lytton, Edward Bulwer Lytton, Baron. Harold: The Last of the Saxon Kings. London; New York: Routledge, [I8-?].

—. The LastDays of Pompeii.New York: Book League of America, [18-?].

—. Paul Clifford; Eugene Aram. Chicago: Belford, Clarke, [18-?].

Mackenzie, Compton. Sinister Street. New York: Appleton, I9I4.

Major, Charles. When Knighthood Was in Flower, or, The Love Story of Charles Brandon and Mary Tudor.... Rewritten and rendered into modern English from Sir Edwin Caskoden's memoir. Indianapolis, Indiana: Bowen Merrill, I899.

Malet, Lucas. Colonel Enderby's Wife. 2nd ed. London: Kegan Paul, Trench, I885.

- Deadham Hard: A Romance. New York: Dodd, Mead, I9I9.

- The History of Sir Richard Calmady: A Romance. 2nd ed. London: Methuen, I90I. Methuen, 1902.

The History of Sir Richard Calmady: a Romance. 3rd ed. London:

Mansfield, Katherine. Bliss and Other Stories. London: Constable, [1923].

Mare, Margaret Laura and Alicia C. Percival . Victorian Best-Seller: the World of Charlotte M. Yonge. With a frontispiece in colour and 16 plates in half-tone. London: Harrap, [ I947].

Marryat, Florence. Fighting the Air. London: Chatto and Windus, I885.

—. The Nobler Sex. New York, London: Street \& Smith, [I8-?].

—. The Spirit World. 2nd ed. London: White, I895. 
Mulock)

(See other works by Florence Marryat under Craik, Dinah Maria

Marshall, Beatrice. Emma Marshall: A Biographical Sketch.London:Seeley, I90I. Abigail Templeton, or, Brave Efforts: A Story of To-day. With four illustrations by J. Finnemore. London: W. \& R. Chambers, I897.

Marshall, Emma. Little Queenie: A Story of Child-Life Sixty Years Ago. New ed. London: Shaw, [1892?].

Martineau, Harriet. Feats on the Fjord; and, Merdhin. New York: Dutton, [I9I5].

Mathers, Helen. “Cherry Ripel”: A Romance. 3rd ed. London: Bentley, I878.

Meredith, George. Diana of the Crossways. New York: C. Scribner's Sons, I9I5.

- Lord Ormont and His Aminta. New York: C. Scribner's Sons, I9I0.

Meynell, Alice Christiana Thompson. Prose and Poetry: Centenary Volume. Edited by $\mathrm{F}[$ rederick $] \mathrm{P}[$ age $]$.. . [et al.]. With a biographical and critical introduction by V. Sackville-West. London: Cape, 1947.

Meynell, Viola. Alice Meynell: A Memoir. London: Cape, [1929].

Mill, John Stuart. On Liberty; the Subjection of Women. New York: Holt, I895.

Mitchell, S. Weir [Silas Weir]. Hugh Wynne, Free Quaker: Sometime Brevet Lieutenant-Colonel on the Staff of His Excellency General Washington.Withintroduction and notes by Vincent B. Brecht. New York: Century Co., I922. (Cover: School ed.)

Molesworth, Mrs. Mary: A Nursery Story for Very Little Children. Illustrated by L. Leslie Brooke. London: Macmillan, I893.

Macmillan, I894.

My New Home. Illustrated by L. Leslie Brooke. London: My New Home. Illustrated by L. Leslie Brooke. Introduction by Gillian Avery. London: Gollancz, 1968. 
- The Tapestry Room: A Child's Romance. Illustrated by Walter Crane. London: Stacey, 1972.

Nesbit, E. [Edith]. The Story of the Amulet. Illustrated by J.S. Goodall. New York: Looking Glass Library; distributed by Random House, [I960].

. Wet Magic. Illustrated by H.R. London: Benn; New York: Coward-McCann, [1958].

Olcott, Charles S. (Charles Sumner). George Eliot: Scenes and People in Her Novels. New York: Crowell, [19I0].

- The Makers of Florence. New York: Caldwell, [18-?].

- The Autobiography and Letters of Mrs. M. O.W. Oliphant. Arranged and edited by Mrs. Harry Coghill. 3d ed., rev. Edinburgh: Blackwood, I899.

—. The Ladies Lindores. Chicago: Belford, Clarke, [18-?].

- The Makers of Venice: Doges, Conquerors, Painters, and Men of Letters. With illustrations by R.R. Holmes. London, New York: Macmillan, I888. The Makers of Venice: Doges, Conquerors, Painters, and Men of Letters. With illustrations by R.R. Holmes. London, New York: Macmillan, I89I. - Miss Marjoribanks. New York: Garland, I976. (Reprint of the I866 ed. published by W. Blackwood, Edinburgh.)

- The Perpetual Curate. New York: Garland, 1975. (Reprint of the $1864 \mathrm{ed}$. published by W. Blackwood, London.)

- Phoebe, Junior. New York: Garland, 1976. (Reprint of the I876 ed. published by Hurst and Blackett, London.)

- The Rector and the Doctor's Family. New York: Garland, I975. (Reprint of the I863 ed. published by W. Blackwood, Edinburgh.)

- Salem Chapel. New York: Garland, I976. (Reprint of the I863 ed. published by W. Blackwood, Edinburgh.)

Orczy, Emmuska Orczy, Baroness. Links in the Chain of Life. London, New York: Hutchinson, [I947].

—. Petticoat Government. London: Hutchinson, I9I0. 
Ouida. A Dog of Flanders. New York: Caldwell, [18-?].

Owen, Mrs. Octavius Freire. The Heroines of History. London: Routledge, [1854?].

Page, Thomas Nelson. The Old Gentleman of the Black Stock. Illustrated by Howard Chandler Christy. New York: Scribner's Sons, I90I.

Palmer, George Herbert. The Life of Alice Freeman Palmer. Boston: Houghton, Mifflin; Cambridge: Riverside Press, 1908.

Pankhurst, Christabel, Dame. The Lord Cometh:The World Crisis Explained. Foreword by the Rev. F.B. Meyer, D.D. Rev. ed. London: Morgan \& Scott, [1934].

Pater,Walter. The Renaissance: Studies in Art and Poetry. New York: Macmillan, 1909.

Patmore, Coventry Kersey Dighton. The Angel in the House. 7th lib. ed. London: Bell \& Son, 1896. and Fields, 1856.

Phelps, Elizabeth Stuart. Chapters from a Life. Boston, New York: Houghton, Mifflin, 1897.

—. Doctor Zay. Boston: Houghton, Mifflin, I882.

—. Donald Marcy. Boston: Houghton, Mifflin, [c. I893].

—. The Gates Ajar. Boston: Fields, Osgood, I869.

—. The Gates Between. Boston; New York: Houghton, Mifflin, I887.

Phelps, Elizabeth Stuart and Herbert D.Ward. The Master of the Magicians. Boston; New York: Houghton, Mifflin, I890.

Phillpotts, Eden. The Secret Woman. London: Collins, [19-?].

Preston, Anna. The Record of a Silent Life. London: Secker, New York: Huebsch, I9I3.

Reade, Charles. Griffith Gaunt, or, Jealousy; Peg Woffington. Ed. deluxe. Philadelphia: Nottingham Society, [19-?]. 
Society, [19-?].

It Is NeverToo Late to Mend. Ed. deluxe. Philadelphia: Nottingham

. A Simpleton; White Lies. Ed. deluxe. Philadelphia: Nottingham Society, [19-?].

—. A Terrible Temptation. New York: Davis, I887.

Reed, Andrew. Martha: A Memorial of an Only and Beloved Sister. New York: Harper \& Brothers, I835.

Rhys, Ernest. Everyman Remembers. New York: Cosmopolitan, I93I.

Rita. Miss Kate, or, Confessions of a Caretaker. London:White, [I889?].

Ritchie, Anne Thackeray. Records of Tennyson, Ruskin, Browning. Port Washington, N.Y.: Kennikat, [I969].

—. Toilers and Spinsters: And Other Essays. London: Smith Elder, I890.

Roberts, Elizabeth Madox. The Great Meadow. New York: Literary Guild, I930.

- The Time of Man. New York: Viking Press, 1926.

Roberts, R. Ellis [Richard Ellis]. Portrait of Stella Benson. London: Macmillan, I939.

Robins, Elizabeth. The Magnetic North. New York: Stokes, 1904.

Roe, Edward Payson. Opening a Chestnut Burr. London: Nicholson \& Sons, [18-?].

What Can She Do? London: Routledge and Sons, I883.

Romanes, Ethel Duncan. Charlotte Mary Yonge: An Appreciation. London: Mowbray, I908.

Rossetti, Dante Gabriel. Poems. New ed. Boston: Roberts, I882.

Ruck, Berta. In Another Girl's Shoes. With illustrations by E. C. Caswell. New York: Dodd, Mead, I9I6.

Miss Million's Maid: A Romance of Love and Fortume.With illustrations by E.C. Caswell. New York: Dodd, Mead, I9I7. 
Ruskin, John. Selected Writings of John Ruskin. Edited and introduced by Peter Quennell. London: Falcon Press, 1952.

- Sesame and Lilies: Three Lectures. Revised and enlarged ed. New York: Lovell, Coryell, [18-?].

Rutherford, Mark. The Works of Mark Rutherford. Edited by his friend Reuben Shapcott. London: Unwin, [19-?].

Sackville-West, V.(Victoria). All Passion Spent. London: Hogarth Press, I93I.

Schreiner, Olive. Dreams. Author's ed. Boston: Little, Brown, I9I4.

- Dreams. Author's ed. Boston: Little, Brown, I9I8.

- The Story of an African Farm. Introduction by Francis Brett Young. New York: The Modern Library, [1927].

- Undine. With an introduction by S. C. Cronwright-Schreiner. New York: Harper, 1928.

Scott, Walter, Sir. The Monastery. Woodstock ed. New York: Routledge, [I8-?].

Periodical Criticism. Edinburgh: Cadell, I835-I836.

Scudder, Townsend. Jane Welsh Carlyle. New York: Macmillan, I939.

Sedgwick, Catharine Maria. Clarence, or, A Tale of Our Own Times. Author's rev. ed. New York: J. C. Derby; Boston: Phillips, Sampson, 1854.

Sewell, Elizabeth Missing. Margaret Percival; The Experience of Life. New York: Garland, 1977. (Reprint of the I847 ed. of Margaret Percival, and of the $1853 \mathrm{ed}$. of The Experience of Life, both published by Longman, Brown, Green \& Longmans, London.)

Sidney, Margaret. The Adventures of Joel Pepper. Illustrated by Sears Gallagher. Boston: Lothrop, Lee \& Shepard, c. 1900.

Lothrop, [c. I892]. Lothrop, I893.

Five Little Peppers Midway. Illustrated by W. L. Taylor. Boston: 
- Phronsie Pepper. The Youngest of the "Five Little Peppers." Illustrated by Jessie McDermott. Boston: Lothrop, c. 1897.

Sinclair, Catherine. Holiday House: A Book for the Young. With an introduction by Barbara Willard. [London]: Hamilton, [1972].

Sinclair, May. The Belfry. New York: Boni and Liveright, c. I9I6.

—. The Divine Fire. New York: Holt, 1904.

Skene, Felicia. Use and Abuse; Hidden Depths. New York: Garland, 1975. (Reprint of the $1849 \mathrm{ed}$. of Use and Abuse, published by F. \& J. Rivington, London; and of the I866 ed. of Hidden Depths, published by Edmonston and Douglas, Edinburgh.)

Southworth, Emma Dorothy Eliza Nevitte. The Discarded Daughter, or, The Children of the Isle. New York: Lupton, [c. I876].

—. Self-Raised; or, From the Depths. New York: Hurst, [18-?].

Steel, Flora Annie Webster. Mistress of Men. New York: Stokes, I9I7.

—. A Prince of Dreamers. London: Heinemann, I908.

—. Red Rowans. New York, London: Macmillan, 1898.

Stevenson, Robert Louis. The Black Arrow: A Tale of the Two Roses. New York: C. Scribner's Sons, I9I5.

The Merry Men, and Other Tales and Fables, Strange Case of Dr. Jekyll and Mr. Hyde. New York: C. Scribner's Sons, I9I5.

—. New Arabian Nights. New York: C. Scribner's Sons, I9I5.

—. Treasure Island. New York: C. Scribner's Sons, I9I5.

Stodart, M.A. Female Writers. Thoughts on Their Proper Sphere, and on Their Powers of Usefulness. London: Seeley and Burnside, I842.

Stopes, Marie Carmichael. Enduring Passion: Further New Contributions to the Solution of Sex Difficulties Being the Continuation of Married Love. 2nd ed., rev. and including all prescriptions. London: Putnam's, 1929.

Married Love. ANew Contribution to the Solution of Sex Difficulties. New York: Eugenics, I93I. 
Stowe, Harriet Beecher. A Key to Uncle Tom's Cabin; presenting the original facts and documents upon which the story is founded. Together with corroborative statements verifying the truth of the work. Boston: Jewett; Cleveland: Jewett, Proctor \& Worthington; [etc.], 1853.

—. Pink and White Tyranny: a Society Novel. Boston: Roberts, I88I.

- Poganuc People: Their Loves and Lives. New York: Fords, Howard, \& Hulbert, c. I878.

Uncle Tom's Cabin, or, Life Among the Lowly. New ed. With an introductory account of the work by the author. Boston: Houghton Mifflin, I890.

Strachey, Ray. Women's Suffrage and Women's Service:The History of the London and National Society for Women's Service. Westminister: London and National Society for Women's Service, 1927.

Stretton, Hesba. The Children of Cloverley. 33rd impression. London: Religious Tract Society, [I8-?].

—. Jessica's First Prayer. London: Religious Tract Society, [19-?].

Strother, Emily Vielé. Eve Dorre: the Story of Her Precarious Youth. With a frontispiece in color by Grace Cochrane Sanger. New York: Dutton, cI9I5.

Swan, Annie S. My Life: An Autobiography. London: Nicholson \& Watson, 1934.

Tarbell, Ida M. [Ida Minerva]. He Knew Lincoln. New York: Doubleday, Page, 1909.

Tautphoeus, Baroness Jemima Montgomery. At Odds. Philadelphia: Lippincott, I886.

Putnam's sons, [1892].

—. Quits. Philadelphia: Lippincott, I888.

Tennyson, BaronAlfred Tennyson. The Poetical Works of Alfred Tennyson. New York: Burt, [I8-?]. 
Thackeray, William Makepeace. The History of Henry Esmondy, A Colonel in the Service of Her Majesty Queen Anne. Edited by William Makepeace Thackeray. London: Nelson and Sons, [19-?].

- The Newcomes: Memoirs of a Most Respectable Family. Edited by Arthur Pendennis. London: Nelson, [19-?].

—. Vanity Fair:ANovelWithoutaHero.London:Nelson andSons,[19-?].

—. TheVirginians: A Tale of the Last Century.London:NelsonandSons, [19-?].

Trollope, Anthony. The Small House at Allington. London: Dent \& Sons; New York: Dutton, [1934].

Utter, Robert Palfrey and Gwendolyn Bridges Needham. Pamela's Daughters. London: Dickson, 1937.

Victoria, Queen of Great Britain. Leaves from the Journal of Our Life in the Highlands, from I848 to I861:To Which Are Prefixed and Added Extracts from the Same Journal Giving an Account of EarlierVisits to Scotland, and Tours in England and Ireland, and Yachting Excursions. Edited by Arthur Helps. New York: Harper \& Brothers; Chicago: Griggs, I868.

Voynich, E. L. [Ethel Lillian]. The Gadfly. New York: Holt, 1906.

—. An Interrupted Friendship. New York: Macmillan, I9I0.

—. Olive Latham. Philadelphia, London: Lippincott, 1904.

Vries, Leonard de. Little Wide-Awake: An Anthology from Victorian Children's Books and Periodicals in the Collection of Anne and Fernand G. Renier. Ist U.S. ed. Cleveland: World Pub. Co., [1967].

Vyver, Bertha. Memoirs of Marie Corelli. With an epilogue by J. Cuming Walters. London: Rivers, 1930.

Wald, Lillian D. The House on Henry Street. With illustrations from etchings and drawings by Abraham Phillips and from photographs. New York: Holt, I9I5.

Walford, Lucy Bethia. The Baby's Grandmother. New ed. London: Griffith, Farran, [18-?].

Ward, Mrs.Humphry. The Case of Richard Meynell. New York: Hurst, [cI9II]. 
I9I4.

- Delia Blanchflower. New York: Hearst's International Library,

- Eleanor. New York: Harper \& Brothers, 1900.

Elizabeth's Campaign. Frontispiece in color by C. Allan Gilbert. New York: Dodd, Mead, I9I8.

- England's Effort. Letters to an American Friend. With a preface by Joseph H. Choate. New York: C. Scribner's Sons, [cI9I6].

Dodd, Mead, 1920.

- Harvest. Frontispiece in color by Allan Gilbert. New York:

- Helbeck of Bannisdale. London: Smith, Elder, 1898.

- Helena. Frontispiece in colour by C. Allan Gilbert. New York: Dodd, Mead, I9I9.

—. The History of David Grieve. New York: Macmillan, I892 [c. I89I].

—. The History of David Grieve. New York: Grosset \& Dunlap, 1906.

—. Lady Connie. Illustrated by Albert Sterner. New York: Hearst's International Library Co., I9I6.

Lady Merton, Colonist. Frontispiece by Albert Sterner. New York: Doubleday, Page, I9I0.

—. Marcella. New York: Macmillan, I894.

—. Marriage á la mode. Illustrated by Fred Pegram. New York: Doubleday, Page, 1909.

- The Marriage of William Ashe. Illustrated by Albert Sterner. Special limited ed. New York: Grosset \& Dunlap, 1905.

—. Miss Bretherton. New York: Ivers, [19-?].

- Missing. Frontispiece in color by C. Allan Gilbert. New York: Dodd, Mead, I9I7.

Missing. Illustrated with scenes from the photoplay of the same name released by Famous Players-Lasky Corporation. New York: Grosset \& Dunlap, c. I9I7. 
—. Sir George Tressady. New York: Macmillan, c. 1896.

—. The Story of Bessie Costrell. New York; London: Macmillan, I895.

- The Testing of Diana Mallory. Illustrated by W. Hatherell, R.I. New York and London: Harper \& Brothers, 1908.

—. A Writer's Recollections. New York: Harper \& Brothers, I9I8.

Warner, Susan. Queechy. London:Warne, [I8-?].

- The Wide Wide World. London: Nisbet, [I85I].

—. Wych Hazel. New York: G.P. Putnam's Sons, I888.

Webb, Mary Gladys Meredith. Precious Bane. London: Cape, [1924].

Wells, Catherine. The Book of Catherine Wells. With an introduction by her husband H.G. Wells. Garden City, N.Y.: Doubleday, Doran, 1928.

Wells, H. G. [Herbert George]. Joan and Peter: The Story of an Education. London, New York, Toronto and Melbourne: Cassell, I9I8.

—. Mr. Britling Sees It Through. New York: Macmillan, I9I6.

—. The Research Magnificent. New York: Macmillan, I9I5.

West, Rebecca, Dame. The Fountain Overflows. London: Reprint Society, 1958.

- The Harsh Voice: Four Short Novels. Garden City, N.Y:: Doubleday, Doran, 1937.

Wharton, Edith. The Children. New York; London: Appleton, I928.

—. Crucial Instances. New York: C. Scribner's Sons, I909.

—. A Son at the Front. New York: C. Scribner's Sons, 1923.

- The Valley of Decision. New York: C. Scribner's Sons, 1902.

Wingate, Charles E. L. [Edgar Lewis]. Shakespeare's Heroines on the Stage. New York: Crowell, [1895].

Wood, Mrs.Henry, The Channings. London; New York: Cassell, I908.

—. The Channings. With illustrations by H.H. Flère. London: S. W. Partridge, [19-?]. 
—. Danesbury House. Illustrated by Sydney Cowell. London: Collins, [I8-?].

—. Danesbury House. Glasgow: Scottish Temperance League, I896.

_. East Lynne. London: R. Bentley and Son, I895.

_. East Lynne, or, The Earl's Daughter. New York: Hurst \& Co., [18-?].

—. George Canterbury's Will. London: R. Bentley \& Son, I888.

_. Johnny Ludlow: London: R. Bentley and Son, I896.

—. Mrs. Halliburton's Troubles. [London]: Nelson, [19-?].

_. Roland Yorke: a Sequel to the Channings. London: Macmillan, 1907.

—. The Shadow of Ashlydyat. London: Milner, [I8-?].

- The Shadow of Ashlydyat. London: Macmillan, I902.

Woolson, Constance Fenimore. For the Major; and Selected Short Stories. Edited for the modern reader by Rayburn S. Moore. New Haven: College \& University Press, [1967].

Worboise, Emma Jane. Grace Hamilton’s School Days. London: Heywood, [I8-?].

Violet Vaughan, or, The Shadows of Warneford Grange. Special ed. London: Clarke, [18-?].

Wylie, Elinor. Jennifer Lom: A Sedate Extravaganza... Illuminating Episodes in the Lives of Hon. Gerald Poynyard and His Bride. New York: Doran, 1923.

Yonge, Charlotte Mary. The Armourer's Prentices. New ed. London, New York: Macmillan, 1904.

—. ABook of Worthies: Gathered from the Old Histories and Now Written Anew.

New ed. New York: Macmillan, I882.

Macmillan, I9I4.

The Chaplet of Pearls. Illustrated by W. J. Hennessy. London: Burt, [19-?]. The Chaplet of Pearls, or, The White and Black Ribaumont. New York: 
The Clever Woman of the Family. Illustrated by Adrian Stokes. London: Macmillan, I882.

- The Constable's Tower, or, The Times of Magna Charta. New York: Whittaker, I89I.

—. The Daisy Chain, or, Aspirations: a Family Chronicle. Illustrated by J. Priestman Atkinson. London, New York: Macmillan, I889.

—. Dove in Eagle’s Nest. New York: Hurst, [1866?].

- Heartsease, or, The Brother's Wife. Illustrated by Kate Greenaway. London; New York: Macmillan, I897.

- The Heir of Redclyffe. New York: Burt, [18-?].

- The Heir of Redclyffe. New York: Appleton, I858.

- Hopes and Fears, or, Scenes from the Life of a Spinster. Illustrated by Herbert Gandy. London, New York: Macmillan, I888.

. The Little Duke: Richard the Fearless. New ed. London: Macmillan, I88I

—. The Little Duke: Richard the Fearless. London: Macmillan, I889.

—. The Long Vacation. London: New York: Macmillan, I895.

- The Pillars of the House, or, Under Wode, Under Rode. Illustrated by Herbert Gandy. London: Macmillan, I880.

- The Prince and the Page: A Story of the Last. Frontispiece by Adrian Stokes. New ed. London: Macmillan, I883.

-Psand Q's, or, The Question of Putting Upon, and, Little Lucys Wonderful Globe. London: Macmillan, I899. 1878 .

The Story of the Christians and Moors of Spain. London: Macmillan, 1877.

Zangwill, Edith Ayrton. The Call. London: Allen \& Unwin, I924. 